\title{
Green options for anti-corrosion of high strength concrete incorporating ternary pozzolan materials
}

\author{
Yuan-Yuan Chen ${ }^{\mathrm{a}}$, Chien-Jou Yang \\ Department of Architecture, Hwa Hsia University of Technology, New Taipei City 235, Taiwan
}

\begin{abstract}
This paper applied the densified mixture design algorithm(DMDA) method by incorporating ternary pozzolans (fly ash, slag and silica fume; mix I and mix II) to design high strength concrete (HSC) mixtures with w/cm ratios from 0.24 to 0.30 . Concrete without pozzolans was used as a control group (mix III, w/c from 0.24 to 0.30 ), and silica fume (5\%) was added as a substitute for part of the cement and set as mix IV. Experiments performed compressive strength, four-point resistance meter to measure the conductivity, and rapid chloride ion penetrability tests (ASTM C1202) were assessed the anti-corrosion. The life cycle inventory of LEED suggested by the PCA indicated the green options for cementitious materials. Results showed that mix I and II indicated cement used, $\mathrm{CO}_{2}$ reduction, raw materials and energy consumption all decreased more 50\% than mix III, and mix IV was 5\% less. The compressive strength and anti-corrosion levels showed that mix I and II were better than mix III and IV, and with ternary pozzolans could enhance the long-term durability (92 days) due to a resistivity greater $20 \mathrm{~K} \Omega-\mathrm{cm}$ and a charge passed lower than 2000 Coulombs. HSC with an appropriate design could reduce the carbon footprint and improve the durability.
\end{abstract}

\section{High strength concrete and corrosion}

The definition of high-strength concrete (HSC) is the specified strength greater $41 \mathrm{MPa}$ (6000 psi) [13]. HSC mixtures have two key characteristics: a low water-to-cement (cementitious) ratio and a high heat of hydration [1]. These factors lead to the thermal stress between the hydration products of the paste and aggregates, and cause inconsistent deformation of the interface, in turn forming many micro and thermal cracks [4-7]. That is a severe durability problem for HSC, especially when exposed in or adjacent marine environment. Corrosion is the most important and critical issue for concrete structures in Taiwan (because the country was surrounded by the sea). Many factors influenced the heat of hydration of HSC. The most commonly used method for creating HSC was incorporating pozzolans (post-industry products- such as fly ash, blast-furnace slag and silica fume; natural such as calcined clay, calcined shale, and meta-kaolin) in the mixture to decrease its cement content and enhance the fresh, hardened properties and long-term durability [4, 7]. Water, oxygen and chloride ions play important roles in the corrosion of embedded steel and the cracking of concrete. It is obvious that permeability of concrete is the key to control the various processes involved in these phenomena. Concrete mixture properties to ensure low permeability including low water-to-cementitious (w/cm), adequate cement content, control of aggregate size and grading, and use of mineral admixtures [4].

\footnotetext{
${ }^{a}$ Corresponding author : cyy@cc.hwh.edu.tw
} 
The ACI 318-11 structural concrete building code is based on the exposure classes presented in Table 4.2.1(P: Requiring low permeability; C: Corrosion protection of reinforcement). It states that concrete mixtures should comply with the most restrictive requirements according to Table 4.3.1 (P1: In contact with water where low permeability is required; $\mathrm{C} 2$ : Concrete exposed to moisture and an external resource of chlorides from deicing chemicals, salt, brackish water, seawater, or spray from these resources). For permeability requirements, the P1 class should have a w/cm less than 0.50 and a specified strength $\left(f^{\prime}{ }_{c}\right)$ was greater than 4000 psi and the $\mathrm{C} 2$ class should have a w/cm below 0.40 and $f^{\prime}{ }_{c}$ was above 5000 psi [8]. Proper consolidation(compactness) and curing of concrete are equally essential [4]. One standard method that provides a performance-based indicator of low permeability of concrete is ASTM C1202 for anti-corrosion experiments on permeability and corrosion resistance, which has been found to be reliable in laboratory evaluation than for acceptance in the field. The use of ASTM C1202 to test concrete mixtures proposed for use provides additional information on the performance of these mixtures [9]. For the Confederation Bridge linking Prince Edward Island with New Brunswick in mainland Canada (1997), the anti-corrosion performance of the concrete exterior exposed to a seawater environment showed that it was free crack, and that the higher electrical resistance is much more important than a lower permeability [10, 11].

\section{Pozzolans and LEED}

The main ingredients of concrete are coarse aggregates, fine aggregates, cementitious materials (cement and pozzolans), and water (included liquid admixture) [4-6]. The carbon footprint for concrete mainly emitted constitute was cement, contributes 5 per cent of annual anthropogenic global $\mathrm{CO}_{2}$ production $[12,13]$. According to a 2015 statistic of the worldwide cement production by major producing countries from 2010 to 2015 [14], China, India, and the United States were among the global top three. The production exceeded more than 40 billion metric tons in 2015 . For every 1000 $\mathrm{kg}$ of cement manufactured, $\mathrm{CO}_{2}$ emissions were reduced from $927 \mathrm{~kg}$ (before) to $800 \mathrm{~kg}$ (now) [12, 15]. The cement industry is a high-intensity manufacturing process. Every $1000 \mathrm{~kg}$ of cement produced consumes $1613 \mathrm{~kg}$ of raw materials (containing $72 \%$ of limestone, $13 \%$ of cement rock, $3 \%$ of shale, $4 \%$ of clay, and $2 \%$ of sand). The temperature at the lower end of the kiln is $1870{ }^{\circ} \mathrm{C}$. In the hottest part of the kiln, the raw materials reach a temperature of $1480^{\circ} \mathrm{C}$ and melt. The molten material from the kiln, known as clinker, is ground into cement. A small amount of gypsum is added to the cement to control its setting time. The weighted average energy consumption, including fuel and electricity, during cement production is $4.8 \mathrm{GJ} / \mathrm{metric}$ ton of cement [16-20]. To process slag, it is from a blast-furnace during the production of pig iron, can be used a supplementary cementitious material as a partial replacement for Portland cement in concrete, It quenched with water and ground. One metric ton of slag uses about $14 \%$ of energy to produce one metric ton of cement. Additionally, one metric ton of slag produces about $2 \%$ of $\mathrm{CO}_{2}$ emissions to produce one metric ton of cement [16, 21]. The carbon footprint for fly ash and silica fume were regarded as being zero because of recycling and the prevention of air pollution. $\mathrm{CO}_{2}$ emissions were produced by their main products, electricity and siliceous-steel.

The supplementary cementitious materials (fly ash, ground granulated blast-furnace slag, silica fume, and others pozzolans) used for concrete could contribute to green design as follows: (1) As industrial by-products, their use as a partial replacement for Portland cement does not contribute to the energy and $\mathrm{CO}_{2}$ impacts of cement in concrete; (2)Raw material usage is reduced in the manufacture of concrete; (3) Landfill disposal is reduced and there is an increased use of recovered industrial materials; and (4) SCMs improve concrete service life through greater concrete durability [21-24]. The commonly used materials include fly ash ( $\mathrm{C}$ and $\mathrm{F}$ classes), ground granulated blast-furnace slag, and silica fume, especially fly ash and slag. Worldwide production exceeded over a billion metric tons. These post-industry products were recycled, reused, and reduced to avoid air pollution and to waste a large amount of landfill disposal fields. In many countries, pozzolans have been a recycled resource incorporated in concrete to enhance their properties. Pozzolans were beneficial for improving the 
durability of anti-corrosion, sulfate resistance, alkali-silica reaction, and regarded as the fifth required material in concrete.

The Leadership in Energy and Environmental Design(LEED) Green Building Rating System was developed by the U.S. Green Building Council (USGBC) in 1998. The LEED rating system is a voluntary, consensus-based, mark driven rating system based on existing proven technology [25-28]. It evaluates environmental performance from a whole building perspective over a building's life cycle, providing a definitive standard for what constitutes a "green building." The rating system is organized into five environmental categories: Sustainable Sites, Water Efficiency, Energy \& Atmosphere, Materials \& Resources, and Indoor Environmental Quality. An additional category, namely Innovation \& Design Process, addresses sustainable building expertise as well as design measures not covered under the five environmental categories [25]. LEED is a performance-based system where credits are earned for satisfying criteria designed to address specific environmental impacts inherent in the design, construction, and operation and maintenance of buildings. For the LEED rating system for New Construction and Major Renovations (LEED-NC2.2) different levels of green building certification are awarded based on the total credits earned rating including Certified, Silver, Gold, and Platinum. The LEED system is designed to be comprehensive in scope yet simple in operation. The use of fly ash and slag can earn about 6 possible points (Sustainable Sites- 1 point, Material \& Resources - 4 points, and Innovation in Design - 1 point) [29, 30].

The green options for anti-corrosion of high strength concrete with quaternary cementitious materials (cement, fly ash, slag, and silica fume) applied a densified mixture design algorithm(DMDA) and ACI 211.1R methods to examine the mixture feasibility. The life cycle inventory for the concrete mixture suggested by the Portland Cement Association (PCA) [31-35] and properties comprised of cement used, $\mathrm{CO}_{2}$ emission, raw materials, energy consumption, compressive strength, surface resistivity, and charge passed.

\section{Materials, Mix design and Experiments}

\subsection{Materials}

The component and properties of cementitious materials are respectively matched ASTM C150 (cement), ASTM C618 (fly ash), ASTM C989 (slag) and ASTM C1240(silica fume), as shown in Table 1. Coarse and fine aggregates met ASTM C33 requirements, as shown in Table 2. Water was potable water conformed to ASTM C94. The high range water- reducing agents was produced by Sica Chem. Corp. used as a high flow agent and conformed to ASTM C494 Type G.

Table 1. Properties of cementitious materials.

\begin{tabular}{|c|c|c|c|c|}
\hline Item & Cement & Fly ash & Slag & Silica fume \\
\hline $\mathrm{SiO}_{2}$ & 22.0 & 51.2 & 34.9 & 97.7 \\
\hline $\mathrm{Al}_{2} \mathrm{O}_{3}$ & 5.6 & 24.3 & 13.5 & 0.7 \\
\hline $\mathrm{Fe}_{2} \mathrm{O}_{3}$ & 3.4 & 6.1 & 0.3 & 0.1 \\
\hline $\mathrm{CaO}$ & 62.8 & 6.3 & 41.8 & 0.4 \\
\hline $\mathrm{MgO}$ & 2.6 & 1.6 & 7.2 & 0.4 \\
\hline $\mathrm{SO}_{3}$ & 2.1 & 0.6 & 1.7 & 0.3 \\
\hline $\mathrm{f}-\mathrm{CaO}$ & 1.1 & - & - & - \\
\hline $\mathrm{TiO}_{2}$ & 0.5 & - & - & - \\
\hline $\mathrm{Na}_{2} \mathrm{O}$ & 0.44 & - & - & - \\
\hline $\mathrm{K}_{2} \mathrm{O}$ & 0.78 & - & - & - \\
\hline $\mathrm{V}_{2} \mathrm{O}_{5}$ & 0.05 & - & - & - \\
\hline
\end{tabular}


Table 2. Properties of aggregates.

\begin{tabular}{l|c|c|}
\hline Properties & Corse Aggregate $^{*}$ & Fine Aggregate $^{* *}$ \\
\hline$G_{s}(S S D)$ & 2.64 & 2.63 \\
\hline$G_{s}(O D)$ & 2.63 & 2.62 \\
\hline Absorption $(\%)$ & 1.1 & 2.2 \\
\hline$D_{\max .}(\mathrm{mm})$ & 12.5 & - \\
\hline$F . M .(\%)$ & 6.08 & 2.82 \\
\hline$U W_{d r y}\left(\mathrm{~kg} / \mathrm{m}^{3}\right)$ & 1,536 & - \\
\hline *: Crushed stone \\
**: River sand
\end{tabular}

\subsection{Mix proportion}

The DMDA [36] and ACI 211.1-09 [37] method applied to design the high strength concrete mixtures with water-to-cementitious material $(\mathrm{w} / \mathrm{c}(\mathrm{m}))$ ratios from 0.24 to 0.30 and different water contents. Ternary pozzolans were incorporated into mix I (5\% slag) and mix II (FA: Slag = 7:3) for a higher slag content. ACI 211.1 without pozzolans was set as the control group (mix III), and 5\% of cement was substituted using silica fume in mix IV. The results of the mix design were as shown in Tables 35 .

Table 3. Mixtures proportion for I groups $\left(\mathrm{kg} / \mathrm{m}^{3}\right)$.

\begin{tabular}{|c|c|c|c|c|c|c|c|c|c|}
\hline $\begin{array}{c}\text { Materials } \\
\mathrm{kg} / \mathrm{m}^{3}\end{array}$ & $\mathrm{I}-246$ & $\mathrm{I}-247$ & $\mathrm{I}-248$ & $\mathrm{I}-276$ & $\mathrm{I}-277$ & $\mathrm{I}-278$ & $\mathrm{I}-306$ & $\mathrm{I}-307$ & $\mathrm{I}-308$ \\
\hline Cement & 284 & 376 & 466 & 217 & 299 & 379 & 197 & 238 & 310 \\
\hline Slag & 16 & 21 & 26 & 12 & 17 & 21 & 11 & 13 & 17 \\
\hline Fly Ash & 266 & 238 & 220 & 264 & 248 & 231 & 264 & 255 & 240 \\
\hline Silica Fume & 15 & 20 & 21 & 12 & 16 & 20 & 10 & 13 & 16 \\
\hline $\begin{array}{c}\text { Coarse } \\
\text { Aggregate }\end{array}$ & 753 & 700 & 648 & 777 & 728 & 680 & 776 & 750 & 706 \\
\hline $\begin{array}{c}\text { Fine } \\
\text { Aggregate }\end{array}$ & 957 & 890 & 824 & 988 & 926 & 865 & 986 & 954 & 897 \\
\hline $\begin{array}{c}\text { Water } \\
\text { (Incl. HRWR) }\end{array}$ & 137 & 157 & 177 & 136 & 156 & 176 & 144 & 156 & 175 \\
\hline Rate(\%) & $\mathbf{2 9}$ & $\mathbf{3 9}$ & $\mathbf{4 8}$ & $\mathbf{2 5}$ & $\mathbf{3 5}$ & $\mathbf{4 4}$ & $\mathbf{2 6}$ & $\mathbf{3 1}$ & $\mathbf{4 0}$ \\
\hline
\end{tabular}

*With respect to mix III $\times 100 \%$.

Table 4. Mixtures proportion for II groups $\left(\mathrm{kg} / \mathrm{m}^{3}\right)$.

\begin{tabular}{|c|c|c|c|c|c|c|c|c|c|}
\hline $\begin{array}{c}\text { Materials } \\
\mathrm{kg} / \mathrm{m}^{3}\end{array}$ & II-246 & II-247 & II-28 & II-276 & II-277 & II-278 & II-306 & II-307 & II-308 \\
\hline Cement & 242 & 338 & 431 & 212 & 259 & 342 & 155 & 197 & 271 \\
\hline Slag & 87 & 87 & 87 & 85 & 85 & 85 & 84 & 84 & 84 \\
\hline Fly Ash & 220 & 204 & 189 & 221 & 213 & 199 & 227 & 219 & 206 \\
\hline Silica Fume & 22 & 26 & 31 & 20 & 22 & 26 & 18 & 19 & 23 \\
\hline $\begin{array}{c}\text { Coarse } \\
\text { Aggregate }\end{array}$ & 831 & 772 & 715 & 833 & 804 & 751 & 856 & 828 & 779 \\
\hline $\begin{array}{c}\text { Fine } \\
\text { Aggregate }\end{array}$ & 882 & 820 & 760 & 885 & 853 & 797 & 909 & 879 & 827 \\
\hline $\begin{array}{c}\text { Water } \\
\text { (Incl. HRWR) }\end{array}$ & 138 & 157 & 177 & 146 & 156 & 176 & 144 & 156 & 175 \\
\hline Rate(\%) & $\mathbf{2 5}$ & $\mathbf{3 5}$ & $\mathbf{4 5}$ & $\mathbf{2 5}$ & $\mathbf{3 0}$ & $\mathbf{4 0}$ & $\mathbf{2 0}$ & $\mathbf{2 6}$ & $\mathbf{3 5}$ \\
\hline
\end{tabular}

$*$ With respect to mix III $\times 100 \%$. 
Table 5. Mixtures proportion for III and IV groups $\left(\mathrm{kg} / \mathrm{m}^{3}\right)$.

\begin{tabular}{|c|c|c|c|c|c|c|}
\hline $\begin{array}{c}\text { Material } \\
\mathrm{kg} / \mathrm{m}^{3}\end{array}$ & III-2411 & III-2711 & III-3011 & IV-2411 & IV-2711 & IV-3011 \\
\hline Cement & 963 & 856 & 770 & 915 & 813 & 731 \\
\hline Slag & - & - & - & - & - & - \\
\hline Fly ash & - & - & - & - & - & - \\
\hline Silica fume & - & - & - & 48 & 43 & 39 \\
\hline $\begin{array}{c}\text { Coarse } \\
\text { Aggregate }\end{array}$ & 633 & 633 & 633 & 633 & 633 & 633 \\
\hline $\begin{array}{c}\text { Fine } \\
\text { Aggregate }\end{array}$ & 471 & 560 & 632 & 413 & 509 & 585 \\
\hline $\begin{array}{c}\text { Water } \\
\text { (Non-HRWRA) }^{\text {Rate(\%) }}\end{array}$ & 231 & 231 & 231 & 231 & 231 & 231 \\
\hline & $\mathbf{1 0 0}$ & $\mathbf{1 0 0}$ & $\mathbf{1 0 0}$ & $\mathbf{9 5}$ & $\mathbf{9 5}$ & $\mathbf{9 5}$ \\
\hline
\end{tabular}

*With respect to mix III $\times 100 \%$.

\subsection{Experiments}

The life cycle inventory for anti-corrosion characteristics by LEED according to the PCA included cement content, $\mathrm{CO}_{2}$ emissions, raw materials, energy consumption, compressive strength (ASTM $\mathrm{C} 39$ at 7, 28, 56 and 92 days), anti-corrosion properties containing electrical resistivity(four-point resistivity meter made by Swiss Proceed at 7, 28, 56, and 92 days) upon contact with different concrete sections, and a rapid chloride ion penetrability test(ASTM C1202, at 92 day) [9] as shown in Table 6.

Table 6. Criteria of RCPT by ASTM C1202.

\begin{tabular}{|c|c|}
\hline Measured Value, Coulombs & Chloride Ion Penetrability \\
\hline$>4000$ & High \\
\hline $4000-2001$ & Moderate \\
\hline $2000-1001$ & Low \\
\hline $1000-101$ & Very Low \\
\hline$<100$ & Negligible \\
\hline
\end{tabular}

\section{Results and discussions}

\subsection{Cement use}

With respect to mix III as being $100 \%$, the cement content of mix I, mix II, and mix IV were as shown in the bottom of Tables 3-5. It indicated that mix IV contained 5\% less cement. The decreasing rates for mix I and mix II were $25 \% \sim 48 \%$ and $20 \% \sim 45 \%$, respectively. The amount of cement for mix I and mix II designed by the DMDA method were 50\% less than mix III. Pozzolans used in the mixtures could dramatically reduce the cement content. However, it must still be compared with each property. According to suggestions from the PCA, the life cycle inventory for various mixtures of cementitious materials including cement and others pozzolans were compared to $\mathrm{CO}_{2}$ emissions, raw materials, and energy consumption as shown in Tables 7-15.

\section{$4.2 \mathrm{CO}_{2}$ emission}

Tables 7-9 show that the $\mathrm{CO}_{2}$ emissions of cementitious material were $927 \mathrm{~kg} / 1000 \mathrm{~kg}$ of cement, GGBFS $2 \%$ emission of cement, and the carbon dioxide footprint from fly ash and silica fume 
regarded as $0 \%$. Calculation results showed that $\mathrm{CO}_{2}$ emissions for mix I and mix II, with respect to mix III as being $100 \%$, were $20 \% \sim 45 \%$ and $20 \% \sim 40 \%$, respectively. The mixtures significantly decreased $50 \%$ more than mix III. The $\mathrm{CO}_{2}$ reduction rate for mix IV was only $5 \%$ similar to the cement reduction. A reduction in the cement content caused a reduction in $\mathrm{CO}_{2}$ emissions. High strength concrete mixtures with multi-pozzolans (mix I and mix II) may allow more carbon reduction.

Table 7. Life cycle inventory for LEED - $\mathrm{CO}_{2}$ emission of binders for mix I.

\begin{tabular}{|c|c|c|c|c|c|c|c|c|c|}
\hline \multicolumn{8}{|c|}{ Life cycle inventory- $\mathrm{CO}_{2}$ emission of binders for concrete mix $\left(\mathrm{kg} / \mathrm{m}^{3}\right)$} \\
\hline $\begin{array}{c}\text { Material } \\
\mathrm{kg} / \mathrm{m}^{3}\end{array}$ & $\mathrm{I}-246$ & $\mathrm{I}-247$ & $\mathrm{I}-248$ & $\mathrm{I}-276$ & $\mathrm{I}-277$ & $\mathrm{I}-278$ & $\mathrm{I}-306$ & $\mathrm{I}-307$ & $\mathrm{I}-308$ \\
\hline Cement & 263 & 349 & 432 & 201 & 277 & 351 & 183 & 221 & 287 \\
\hline Slag & 0 & 0 & 0 & 0 & 0 & 0 & 0 & 0 & 0 \\
\hline Fly ash & 0 & 0 & 0 & 0 & 0 & 0 & 0 & 0 & 0 \\
\hline Silica fume & 0 & 0 & 0 & 0 & 0 & 0 & 0 & 0 & 0 \\
\hline Total & 263 & 349 & 432 & 201 & 277 & 351 & 183 & 221 & 287 \\
\hline Rate(\%) & $\mathbf{2 9}$ & $\mathbf{3 9}$ & $\mathbf{4 8}$ & $\mathbf{2 5}$ & $\mathbf{3 5}$ & $\mathbf{4 4}$ & $\mathbf{2 6}$ & $\mathbf{3 1}$ & $\mathbf{4 0}$ \\
\hline
\end{tabular}

Cement $\mathrm{CO}_{2}$ Emission: $927 \mathrm{~kg} / 1000 \mathrm{~kg}$ Cement;

Slag $\mathrm{CO}_{2}$ Emission: $2 \%$ of $927 \mathrm{~kg} / 1000 \mathrm{~kg}$ Cement;

Fly Ash and Silica Fume $\mathrm{CO}_{2}$ Emission: None.

$*$ With respect to mix III $\times 100 \%$.

Table 8. Life cycle inventory for LEED - $\mathrm{CO}_{2}$ emission of binders for mix II.

\begin{tabular}{|c|c|c|c|c|c|c|c|c|c|}
\hline \multicolumn{8}{|c|}{ Life cycle inventory- $\mathrm{CO}_{2}$ emission of binders for concrete $\operatorname{mix}\left(\mathrm{kg} / \mathrm{m}^{3}\right)$} \\
\hline $\begin{array}{c}\text { Material } \\
\mathrm{kg} / \mathrm{m}^{3}\end{array}$ & II-246 & II -247 & II I-248 & II -276 & II -277 & II -278 & II -306 & II -307 & II -308 \\
\hline Cement & 224 & 313 & 400 & 197 & 240 & 317 & 144 & 183 & 251 \\
\hline Slag & 2 & 2 & 2 & 2 & 2 & 2 & 2 & 2 & 2 \\
\hline Fly ash & 0 & 0 & 0 & 0 & 0 & 0 & 0 & 0 & 0 \\
\hline $\begin{array}{c}\text { Silica } \\
\text { fume }\end{array}$ & 0 & 0 & 0 & 0 & 0 & 0 & 0 & 0 & 0 \\
\hline Total & 226 & 315 & 402 & 199 & 242 & 319 & 146 & 185 & 253 \\
\hline Rate(\%) & $\mathbf{2 5}$ & $\mathbf{3 5}$ & $\mathbf{4 5}$ & $\mathbf{2 5}$ & $\mathbf{3 0}$ & $\mathbf{4 0}$ & $\mathbf{2 0}$ & $\mathbf{2 6}$ & $\mathbf{3 5}$ \\
\hline
\end{tabular}

Cement $\mathrm{CO}_{2}$ Emission: $927 \mathrm{~kg} / 1000 \mathrm{~kg}$ Cement;

Slag $\mathrm{CO}_{2}$ Emission: $2 \%$ of $927 \mathrm{~kg} / 1000 \mathrm{~kg}$ Cement;

Fly Ash and Silica Fume $\mathrm{CO}_{2}$ Emission: None.

$*$ With respect to mix III $\times 100 \%$.

Table 9. Life cycle inventory for LEED - $\mathrm{CO}_{2}$ emission of binders for mix III\&IV.

\begin{tabular}{|c|c|c|c|c|c|c|}
\hline \multicolumn{6}{|c|}{ Life cycle inventory- $\mathrm{CO}_{2}$ emission of binders for concrete $\operatorname{mix}\left(\mathrm{kg} / \mathrm{m}^{3}\right)$} \\
\hline $\begin{array}{c}\text { Material, } \\
\mathrm{kg} / \mathrm{m}^{3}\end{array}$ & III-2411 & III-2711 & III-3011 & IV-2411 & IV-2711 & IV-3011 \\
\hline Cement & 893 & 794 & 714 & 848 & 754 & 678 \\
\hline Slag & 0 & 0 & 0 & 0 & 0 & 0 \\
\hline Fly ash & 0 & 0 & 0 & 0 & 0 & 0 \\
\hline Silica fume & 0 & 0 & 0 & 0 & 0 & 0 \\
\hline Total & 893 & 794 & 714 & 848 & 754 & 678 \\
\hline Rate(\%) & $\mathbf{1 0 0}$ & $\mathbf{1 0 0}$ & $\mathbf{1 0 0}$ & $\mathbf{9 5}$ & $\mathbf{9 5}$ & $\mathbf{9 5}$ \\
\hline
\end{tabular}

Cement $\mathrm{CO}_{2}$ Emission: $927 \mathrm{~kg} / 1000 \mathrm{~kg}$ Cement;

Slag $\mathrm{CO}_{2}$ Emission: $2 \%$ of $927 \mathrm{~kg} / 1000 \mathrm{~kg}$ Cement;

Fly Ash and Silica Fume $\mathrm{CO}_{2}$ Emission: None.

$*$ With respect to mix III $\times 100 \%$. 


\subsection{Raw materials}

The pozzolans used in the concrete were post-industry waste recycled resource materials. Raw materials mainly including limestone and clay (3:1) for the manufacturing process of cement consumed a large amount natural resources. According to the PCA, raw materials required to produce $1000 \mathrm{~kg}$ of cement had to consume more than $1613 \mathrm{~kg}$ of natural resources. The intrusive destruction of nature due to the territorial integrity were destroyed and air pollution were serious problems. The consumption of raw materials for cementitious materials in $\mathrm{kg} / \mathrm{m}^{3}$ were as shown in Tables 10-12. With respect to mix III as being $100 \%$, the amount of raw materials consumed by mix I, mix II, and mix IV were $25 \% \sim 48 \%, 20 \% \sim 45 \%$ and $95 \%$, respectively. Mixtures designed with the DMDA method showed that the raw materials of cementitious materials consumed significantly decreased more than 50\%; meanwhile, the reduction of mix IV was very limited.

Table 10. Life cycle inventory for LEED - Raw materials of mix I for binders.

\begin{tabular}{|c|c|c|c|c|c|c|c|c|c|}
\hline \multicolumn{7}{|c|}{ Life cycle inventory- Raw materials consumption of binders for concrete mix I } \\
\hline $\begin{array}{c}\text { Material } \\
\mathrm{kg} / \mathrm{m}^{3}\end{array}$ & I-246 & I-247 & I-248 & I-276 & I-277 & I-278 & I-306 & I-307 & I-308 \\
\hline Cement & 458 & 606 & 752 & 350 & 482 & 611 & 318 & 384 & 500 \\
\hline Slag & - & - & - & - & - & - & - & - & - \\
\hline Fly ash & - & - & - & - & - & - & - & - & - \\
\hline Silica fume & - & - & - & - & - & - & - & - & - \\
\hline Total & 458 & 606 & 752 & 350 & 482 & 611 & 318 & 384 & 500 \\
\hline Rate(\%) & $\mathbf{2 9}$ & $\mathbf{3 9}$ & $\mathbf{4 8}$ & $\mathbf{2 5}$ & $\mathbf{3 5}$ & $\mathbf{4 4}$ & $\mathbf{2 6}$ & $\mathbf{3 1}$ & $\mathbf{4 0}$ \\
\hline
\end{tabular}

Raw Materials: $1613 \mathrm{~kg} / 1000 \mathrm{~kg}$ Cement.

*With respect to mix III $\times 100 \%$.

Table 11. Life cycle inventory for LEED - Raw materials of mix I for binders.

\begin{tabular}{|c|c|c|c|c|c|c|c|c|c|}
\hline \multicolumn{8}{|c|}{ Life cycle inventory- Raw materials of binders for concrete mix II } \\
\hline $\begin{array}{c}\text { Material, } \\
\mathrm{kg} / \mathrm{m}^{3}\end{array}$ & II-246 & II-247 & II-248 & II-276 & II-277 & II-278 & II-306 & II-307 & II -308 \\
\hline Cement & 390 & 545 & 695 & 342 & 418 & 552 & 250 & 318 & 437 \\
\hline Slag & - & - & - & - & - & - & - & - & - \\
\hline Fly ash & - & - & - & - & - & - & - & - & - \\
\hline Silica fume & - & - & - & - & - & - & - & - & - \\
\hline Total & 390 & 545 & 695 & 342 & 418 & 552 & 250 & 318 & 437 \\
\hline Rate(\%) & $\mathbf{2 5}$ & $\mathbf{3 5}$ & $\mathbf{4 5}$ & $\mathbf{2 5}$ & $\mathbf{3 0}$ & $\mathbf{4 0}$ & $\mathbf{2 0}$ & $\mathbf{2 6}$ & $\mathbf{3 5}$ \\
\hline
\end{tabular}

Raw Material : $1613 \mathrm{~kg} / 1000 \mathrm{~kg}$ Cement.

$*$ With respect to mix III $\times 100 \%$.

Table 12. Life cycle inventory for LEED - Raw materials of mix I for binders.

\begin{tabular}{|c|c|c|c|c|c|c|}
\hline \multicolumn{6}{|c|}{ Life cycle inventory- Raw materials of binders for concrete mix III \& IV } \\
\hline $\begin{array}{c}\text { Material } \\
\mathrm{kg} / \mathrm{m}^{3}\end{array}$ & III-2411 & III-2711 & III-3011 & IV-2411 & IV-2711 & IV-3011 \\
\hline Cement & 1553 & 1381 & 1242 & 1476 & 1311 & 1179 \\
\hline Slag & - & - & - & - & - & - \\
\hline Fly ash & - & - & - & - & - & - \\
\hline Silica fume & - & - & - & - & - & - \\
\hline Total & 1553 & 1381 & 1242 & 1476 & 1311 & 1179 \\
\hline Rate(\%) & $\mathbf{1 0 0}$ & $\mathbf{1 0 0}$ & $\mathbf{1 0 0}$ & $\mathbf{9 5}$ & $\mathbf{9 5}$ & $\mathbf{9 5}$ \\
\hline
\end{tabular}

Raw Material : $1613 \mathrm{~kg} / 1000 \mathrm{~kg}$ Cement.

$*$ With respect to mix III $\times 100 \%$. 


\subsection{Energy consumption}

By PCA reports, the energy consumption for cement manufacturing was $4.8 \mathrm{GJ} / 1000 \mathrm{~kg}$ of cement and ground granulated blast-furnace slag was $14 \%$ per $4.8 \mathrm{GJ} / 1000 \mathrm{~kg}$ of cement for slag grinding. Since the energy consumption was owing to their front of the main products, electricity and siliceoussteel, fly ash and silica fume were regarded as having zero energy consumption. According to Tables 13-15, the energy consumption of cementitious materials in the mixtures with respect to mix III being $=100 \%$, were $26 \% \sim 49 \%$ ( $\operatorname{mix}$ I), 22\% 41\% (mix II), and 95\% (mix IV), respectively. Mix I and mix II used the DMDA method and in comparison to the cementitious materials with mix III, they consumed $50 \%$ less energy.

Table 13. Life cycle inventory for LEED - Energy consumption of binders for mix I.

\begin{tabular}{|c|c|c|c|c|c|c|c|c|c|}
\hline \multicolumn{7}{|c|}{ Life cycle inventory- Energy consumption of binders for concrete I } \\
\hline $\begin{array}{c}\text { Material } \\
\mathrm{kg} / \mathrm{m}^{3}\end{array}$ & I-246 & I-247 & I-248 & I-276 & I-277 & I-278 & I-306 & I-307 & I-308 \\
\hline Cement & 1.36 & 1.80 & 2.24 & 1.04 & 1.44 & 1.82 & 0.95 & 1.14 & 1.49 \\
\hline Slag & 0.01 & 0.01 & 0.02 & 0.01 & 0.01 & 0.01 & 0.01 & 0.01 & 0.01 \\
\hline Fly ash & - & - & - & - & - & - & - & - & - \\
\hline Silica fume & - & - & - & - & - & - & - & - & - \\
\hline Total & 1.37 & 1.81 & 2.26 & 1.05 & 1.45 & 1.83 & 0.96 & 1.15 & 1.50 \\
\hline Rate(\%) & $\mathbf{3 0}$ & $\mathbf{3 9}$ & $\mathbf{4 9}$ & $\mathbf{2 6}$ & $\mathbf{3 5}$ & $\mathbf{4 5}$ & $\mathbf{2 6}$ & $\mathbf{3 1}$ & $\mathbf{4 1}$ \\
\hline
\end{tabular}

Cement Energy Consumption: 4.8GJ/1000kg Cement;

Slag Energy Consumption: 14\% of 4.8GJ/1000kg Cement.

*With respect to mix III $\times 100$.

Table 14. Life cycle inventory for LEED - Energy consumption of binders for mix II.

\begin{tabular}{|c|c|c|c|c|c|c|c|c|c|}
\hline \multicolumn{8}{|c|}{ Life cycle inventory- Energy consumption of binders for concrete II } \\
\hline $\begin{array}{c}\text { Material } \\
\mathrm{kg} / \mathrm{m}^{3}\end{array}$ & II-246 & II-247 & II-248 & II-276 & II-277 & II-278 & II-306 & II-307 & II-308 \\
\hline Cement & 1.16 & 1.62 & 2.07 & 1.02 & 1.24 & 1.64 & 0.74 & 0.95 & 1.30 \\
\hline Slag & 0.06 & 0.06 & 0.06 & 0.06 & 0.06 & 0.06 & 0.06 & 0.06 & 0.06 \\
\hline Fly ash & - & - & - & - & - & - & - & - & - \\
\hline Silica fume & - & - & - & - & - & - & - & - & - \\
\hline Total & 1.22 & 1.68 & 2.13 & 1.08 & 1.30 & 1.70 & 0.80 & 1.01 & 1.36 \\
\hline Rate(\%) & $\mathbf{2 6}$ & $\mathbf{3 6}$ & $\mathbf{4 6}$ & $\mathbf{2 6}$ & $\mathbf{3 2}$ & $\mathbf{4 1}$ & $\mathbf{2 2}$ & $\mathbf{2 7}$ & $\mathbf{3 7}$ \\
\hline
\end{tabular}

Cement Energy Consumption: 4.8GJ/1000kg Cement;

Slag Energy Consumption: $14 \%$ of $4.8 \mathrm{GJ} / 1000 \mathrm{~kg}$ Cement.

$*$ With respect to mix III $\times 100 \%$.

Table 15. Life cycle inventory for LEED - Energy consumption of binders for mix III \& IV.

\begin{tabular}{|c|c|c|c|c|c|c|}
\hline \multicolumn{6}{|c|}{ Life cycle inventory- Energy consumption of binders for concrete III\&IV } \\
\hline $\begin{array}{c}\text { Material } \\
\mathrm{kg} / \mathrm{m}^{3}\end{array}$ & III-2411 & III-2711 & III-3011 & IV-2411 & IV-2711 & IV-3011 \\
\hline Cement & 4.62 & 4.11 & 3.70 & 4.39 & 3.90 & 3.51 \\
\hline Slag & - & - & - & - & - & - \\
\hline Fly ash & - & - & - & - & - & - \\
\hline Silica fume & - & - & - & - & - & - \\
\hline Total & 4.62 & 4.11 & 3.70 & 4.39 & 3.90 & 3.51 \\
\hline Rate(\%) & $\mathbf{1 0 0}$ & $\mathbf{1 0 0}$ & $\mathbf{1 0 0}$ & $\mathbf{9 5}$ & $\mathbf{9 5}$ & $\mathbf{9 5}$ \\
\hline
\end{tabular}

Cement Energy Consumption: 4.8GJ/1000kg Cement;

Slag Energy Consumption: $14 \%$ of $4.8 \mathrm{GJ} / 1000 \mathrm{~kg}$ Cement.

$*$ With respect to mix III $\times 100 \%$. 


\subsection{Compressive strength effect}

The front four-items for life cycle inventory were used to assess the effect of design and production for cementitious materials in the mixtures. Next, tests were executed the performance of hardened properties and durability. This paper performed compressive strength development, surface resistivity, and rapid chloride ion penetrability tests to evaluate anti-corrosion.

The compressive strength development $(7,28,56$, and 92 days) were shown in Tables 16-18. Mix I and mix II with the DMDA method at 28 days showed that the strength ranged from $47 \mathrm{MPa}$ to 73.6 $\mathrm{MPa}$ and 52.4 $\mathrm{MPa}$ to $72.9 \mathrm{MPa}$, respectively. Mix III and mix IV with the ACI 211.1 method indicated strengths from 50.7 $\mathrm{MPa}$ to $54.9 \mathrm{MPa}$ and $53.9 \mathrm{MPa}$ to $54.1 \mathrm{MPa}$, respectively. The cement content of mix III and IV were as twice as that of mix I and II, and the compressive strength increased slowly. At 92 days, mix I, II, III, and IV had strengths of $75.9 \mathrm{MPa} \sim 98.4 \mathrm{MPa}, 65.9 \mathrm{MPa} \sim 99.5 \mathrm{MPa}$, $62 \mathrm{MPa} \sim 65.7 \mathrm{MPa}$, and $65 \mathrm{MPa} \sim 69.7 \mathrm{MPa}$, respectively. The cement amount for mix III was too high to rarely enhance the compressive strength. Mix IV had the same result. Pozzolans in high strength concrete had a very important effect in lowering the heat of hydration and refining the microstructure to be denser to improve the long-term properties. For the compressive strength ratio as shown in Table 19-21, with respect to mix III as being $100 \%$, the strength ratios were $122 \%$ 150\%(mix I), 106\% 151\%(mix II), and 105\% 106\%(mix IV) at 92 days. Mix I and mix II with quaternary cementitious materials increased the compressive strength. Meanwhile, that of mix IV only increased a little.

Table 16. Compressive strength development for mix I(MPa).

\begin{tabular}{|c|c|c|c|c|c|c|c|c|c|}
\hline Ages & I-246 & I-247 & I-248 & I-276 & I-277 & I-278 & I-306 & I-307 & I-308 \\
\hline 7 days & 55.6 & 60.2 & 62.7 & 39.1 & 43.9 & 51.0 & 29.6 & 36.5 & 43.0 \\
\hline 28 days & 67.8 & 80.2 & 73.6 & 57.5 & 60.4 & 65.0 & 47.0 & 49.6 & 59.1 \\
\hline 56 days & 86.3 & 95.1 & 92.2 & 71.9 & 72.4 & 84.0 & 61.5 & 66.9 & 70.4 \\
\hline 92 days & 96.5 & 98.4 & 96.9 & 83.6 & 83.6 & 89.1 & 75.9 & 76.3 & 83.1 \\
\hline
\end{tabular}

Table 17. Compressive strength development for mix II(MPa).

\begin{tabular}{|c|c|c|c|c|c|c|c|c|c|}
\hline Ages & II-246 & II-247 & II-248 & II-276 & II-277 & II-278 & II-306 & II-307 & II-308 \\
\hline 7 days & 40.3 & 50.2 & 63.6 & 35.0 & 43.9 & 48.1 & 30.0 & 39.4 & 35.9 \\
\hline 28 days & 79.9 & 70.3 & 72.8 & 63.3 & 61.0 & 64.4 & 58.7 & 60.7 & 52.4 \\
\hline 56 days & 93.3 & 92.0 & 84.8 & 82.5 & 82.2 & 77.6 & 65.9 & 67.5 & 65.7 \\
\hline 92 days & 99.1 & 99.5 & 98.5 & 93.0 & 85.2 & 83.8 & 65.9 & 79.8 & 76.6 \\
\hline
\end{tabular}

Table 18. Compressive strength development for mix III\&IV(MPa).

\begin{tabular}{|c|c|c|c|c|c|c|}
\hline Ages & III-2411 & III-2711 & III-3011 & IV-2411 & IV-2711 & IV-3011 \\
\hline 7 days & 55.9 & 52.3 & 48.8 & 53.0 & 52.7 & 51.9 \\
\hline 28 days & 59.5 & 54.9 & 50.7 & 53.9 & 54.0 & 54.1 \\
\hline 56 days & 62.7 & 61.2 & 60.7 & 67.7 & 66.0 & 62.0 \\
\hline 92 days & 65.7 & 64.4 & 62.0 & 69.7 & 68.5 & 65.0 \\
\hline
\end{tabular}

Table 19. Relative percent of compressive strength for mix I(as mix III $=100 \%)$.

\begin{tabular}{|c|c|c|c|c|c|c|c|c|c|}
\hline Ages & I-246 & I-247 & I-248 & I-276 & I-277 & I-278 & I-306 & I-307 & I-308 \\
\hline 7 days & 99 & 108 & 112 & 75 & 84 & 98 & 61 & 75 & 88 \\
\hline 28 days & 114 & 135 & 124 & 105 & 110 & 118 & 93 & 92 & 117 \\
\hline 56 days & 138 & 152 & 147 & 117 & 118 & 137 & 101 & 110 & 116 \\
\hline 92 days & 147 & 150 & 150 & 130 & 130 & 138 & 122 & 123 & 134 \\
\hline
\end{tabular}


Table 20. Relative percent of compressive strength for mix II(as mix III=100\%).

\begin{tabular}{|c|c|c|c|c|c|c|c|c|c|}
\hline Ages & II-246 & II-247 & II-248 & II-276 & II-277 & II-278 & II-306 & II-307 & II-308 \\
\hline 7 days & 72 & 90 & 114 & 67 & 90 & 92 & 62 & 81 & 74 \\
\hline 28 days & 134 & 118 & 122 & 115 & 111 & 117 & 116 & 120 & 103 \\
\hline 56 days & 149 & 147 & 135 & 135 & 134 & 127 & 109 & 111 & 108 \\
\hline 92 days & 151 & 151 & 150 & 144 & 132 & 130 & 106 & 129 & 124 \\
\hline
\end{tabular}

Table 21. Relative percent of compressive strength for mix III \& IV(as mix III $=100 \%$ ).

\begin{tabular}{|c|c|c|c|c|c|c|}
\hline Ages & III-2411 & III-2711 & III-3011 & IV-2411 & IV-2711 & IV-3011 \\
\hline 7 days & 100 & 100 & 100 & 95 & 101 & 106 \\
\hline 28 days & 100 & 100 & 100 & 91 & 98 & 107 \\
\hline 56 days & 100 & 100 & 100 & 108 & 108 & 102 \\
\hline 92 days & 100 & 100 & 100 & 106 & 106 & 105 \\
\hline
\end{tabular}

\subsection{Electrical resistivity}

If the concrete structure compactness is high, there are fewer pores; thus, the connection is more difficult. As a result, the conducting channels are decreased or lengthened, and electrical resistivity is enhanced. The conductivity of concrete is mainly influenced by the moisture content. Concrete specimens were cured in saturated lime water, extracted from water, and then dried (interior saturation condition) to measure the surface resistivity at different points of various mixtures. Tables 22-24 show the resistivity development of different mixes. During the early ages (7 days), surface resistivity had a slow development. Only II-248 and IV-2711 groups had more than $20 \mathrm{~K} \Omega$-cm low corrosion occurrence threshold values. After 28 days, the resistivity for mix I, II, and IV groups incorporating various pozzolans significantly increased more than $20 \mathrm{~K} \Omega-\mathrm{cm}$. Adding pozzolans could make the concrete interior microstructure denser to decrease the connection channels. At 92 days, the resistivity of a low w/cm ratio of 0.24 for mix I and mix II displayed poorer conductivity properties (all greater than $100 \mathrm{~K} \Omega-\mathrm{cm}$ ). Mix II groups with a higher pozzolans-binder ratio and adjusted fly ash-slag ratio might increase the compressive strength and resistivity as shown in Tables 17 and Tables 23 . According to ACI 318-11, the design criteria for anti-corrosion of concrete should have a lower the water-to-cementitious ratio and proper content of pozzolans added. In this study, mixtures with multipozzolans and lower w/cm ratios were identified the design results and performance similar to ACI 318-11.

All mixes, with respect to $20 \mathrm{~K} \Omega-\mathrm{cm}$, indicated that the resistivity ratio in comparison to $20 \mathrm{~K} \Omega$ $\mathrm{cm}$ as shown in Table 25-27. At 92 days, the ratios expressed that mix I, mix II, mix III, and mix IV groups were respectively $400 \% \sim 705 \%, 350 \% \sim 705 \%, 85 \% \sim 105 \%$ and $230 \% \sim 290 \%$. Mixtures without pozzolans might have difficulty in avoiding corrosion.

Table 22. Surface resistivity of mix I $(\mathrm{K} \Omega-\mathrm{cm})$.

\begin{tabular}{|c|c|c|c|c|c|c|c|c|c|}
\hline Ages & I-246 & I-247 & I-248 & I-276 & I-277 & I-278 & I-306 & I-307 & I-308 \\
\hline 7 days & 5 & 17 & 17 & 7 & 11 & 10 & 6 & 7 & 8 \\
\hline 28 days & 52 & 74 & 80 & 38 & 51 & 53 & 25 & 36 & 42 \\
\hline 56 days & 94 & 95 & 97 & 69 & 74 & 81 & 44 & 52 & 65 \\
\hline 92 days & 141 & 137 & 126 & 91 & 94 & 91 & 80 & 82 & 82 \\
\hline
\end{tabular}

Table 23. Surface resistivity of mix II $(\mathrm{K} \Omega-\mathrm{cm})$.

\begin{tabular}{|c|c|c|c|c|c|c|c|c|c|}
\hline Ages & II-246 & II-247 & II-248 & II-276 & II-277 & II-278 & II-306 & II-307 & II-308 \\
\hline 7 days & 14 & 15 & 21 & 11 & 8 & 13 & 6 & 9 & 12 \\
\hline 28 days & 73 & 75 & 82 & 64 & 61 & 75 & 43 & 42 & 56 \\
\hline 56 days & 98 & 94 & 100 & 97 & 90 & 89 & 72 & 75 & 72 \\
\hline 92 days & 141 & 134 & 129 & 138 & 124 & 113 & 99 & 94 & 70 \\
\hline
\end{tabular}


Table 24. Surface resistivity of mix III \& IV $(\mathrm{K} \Omega-\mathrm{cm})$

\begin{tabular}{|c|c|c|c|c|c|c|}
\hline Ages & III-2411 & III-2711 & III-3011 & IV-2411 & IV-2711 & IV-3011 \\
\hline 7 days & 11 & 10 & 8 & 17 & 20 & 14 \\
\hline 28 days & 16 & 15 & 13 & 41 & 40 & 30 \\
\hline 56 days & 20 & 18 & 16 & 50 & 47 & 39 \\
\hline 92 days & 21 & 19 & 17 & 58 & 56 & 46 \\
\hline
\end{tabular}

Table 25. Rate of surface resistivity for mix I (as $20 \mathrm{~K} \Omega-\mathrm{cm}=100 \%$ ).

\begin{tabular}{|c|c|c|c|c|c|c|c|c|c|}
\hline Ages & I-246 & I-247 & I-248 & I-276 & I-277 & I-278 & I-306 & I-307 & I-308 \\
\hline 7 days & 55 & 85 & 85 & 35 & 55 & 50 & 30 & 35 & 40 \\
\hline 28 days & 260 & 370 & 400 & 190 & 255 & 265 & 125 & 180 & 210 \\
\hline 56 days & 470 & 475 & 485 & 345 & 370 & 405 & 220 & 260 & 325 \\
\hline 92 days & 705 & 685 & 630 & 455 & 470 & 455 & 400 & 410 & 410 \\
\hline
\end{tabular}

Table 26. Rate of surface resistivity for mix II (as $20 \mathrm{~K} \Omega-\mathrm{cm}=100 \%$ ).

\begin{tabular}{|c|c|c|c|c|c|c|c|c|c|}
\hline Ages & II-246 & II-247 & II-248 & II-276 & II-277 & II-278 & II-306 & II-307 & II-308 \\
\hline 7 days & 70 & 75 & 105 & 55 & 40 & 65 & 30 & 45 & 60 \\
\hline 28 days & 365 & 375 & 410 & 320 & 305 & 375 & 215 & 210 & 280 \\
\hline 56 days & 490 & 470 & 500 & 485 & 450 & 445 & 360 & 375 & 360 \\
\hline 92 days & 705 & 670 & 645 & 690 & 620 & 565 & 495 & 470 & 350 \\
\hline
\end{tabular}

Table 27. Rate of surface resistivity for mix II (as $20 \mathrm{~K} \Omega-\mathrm{cm}=100 \%$ ).

\begin{tabular}{|c|c|c|c|c|c|c|}
\hline Ages & III-2411 & III-2711 & III-3011 & IV-2411 & IV-2711 & IV-3011 \\
\hline 7 days & 55 & 50 & 40 & 85 & 100 & 70 \\
\hline 28 days & 80 & 75 & 65 & 205 & 200 & 150 \\
\hline 56 days & 100 & 90 & 80 & 250 & 235 & 195 \\
\hline 92 days & 105 & 95 & 85 & 290 & 280 & 230 \\
\hline
\end{tabular}

\subsection{Charge passed}

The final options of the life cycle inventory for high strength concrete in this study performed a rapid chloride penetrability test (RCPT) according to ASTM C1202 to evaluate the durability of anticorrosion after 92 days. The test results of the RCPT were as shown in Table 28. Mix I and Mix II were $292 \mathrm{C} \sim 828 \mathrm{C}$ and $251 \mathrm{C} \sim 555 \mathrm{C}$, respectively. From the anti-corrosion on chloride ion penetrability in Table 5, these mixtures showed the rating of chloride ion migration as being at a very low level. Mix III and mix IV were $1003 \mathrm{C} \sim 2091 \mathrm{C}$ and were attributed to a rating of Moderate to Low. Mixtures incorporating pozzolans and applying the DMDA method could enhance the compactness and refine the pore structure of the conducting channels causing a decrease or lengthening [11].

Table 28. Test results of rapid chloride ion penetrability(Coulombs).

\begin{tabular}{|c|c|c|c|c|c|c|c|c|c|}
\hline Mix I & I-246 & I-247 & I-248 & I-276 & I-277 & I-278 & I-306 & I-307 & I-308 \\
\hline 92 days & 292 & 324 & 515 & 414 & 448 & 540 & 517 & 653 & 828 \\
\hline Mix II & II-246 & II-247 & II-248 & II-276 & II-277 & II-278 & II-306 & II-307 & II-308 \\
\hline $\begin{array}{c}92 \text { days } \\
251\end{array}$ & 311 & 352 & 308 & 362 & 402 & 423 & 504 & 555 \\
\hline $\begin{array}{c}\text { Mix III } \\
\& \text { IV }\end{array}$ & III-2411 & III-2711 & III-3011 & IV-2411 & IV-2711 & IV-3011 & - & - & - \\
\hline 92 days & 1977 & 2003 & 2045 & 1090 & 1596 & 1841 & - & - & - \\
\hline
\end{tabular}


Test results of the mixtures used $2000 \mathrm{C}$ (Low level permeability) as the denominator to calculate the corresponding percentage in Table 29. Mix I, mix II, mix III, and mix IV were $15 \% \sim 41 \%, 13 \%$ $27 \%, 99 \% \sim 102 \%$, and $55 \% \sim 92 \%$, respectively. The effects of anti-corrosion with pozzolan mixtures were much better than when no pozzolans were used. Mix II (with a higher amount of slag) was superior to mix I. Further, mix IV with ACI 211-11 and adding silica fume were beneficial in anti-corrosion, but the traditional mix method for mix III without any pozzolans was not suitable for the exposed marine environment. Green options for anti-corrosion mixtures of high strength concrete included the following seven items containing cement used, $\mathrm{CO}_{2}$ emissions, raw materials, energy consumption, compressive strength, the surface resistivity, and charge passed. The first four items were used to evaluate the carbon reduction of cementitious material mixtures, and the last three items were applied to assess the sustainable development of high strength concrete for anti-corrosion. The carbon emissions and resource consumption for mix I and mix II decreased by more than 50\%, and mix IV had a reduction only 5\%, all with respect to mix III. Sustainable development of anti-corrosion properties in this study was regarded as the resistivity and charge passed. The former is a nondestructive test method adopted in the laboratory and field having a simple, light, and fast technique to obtain a lot of useful data; meanwhile, the latter is a widely used destructive test performed in the lab to evaluate the conductivity of concrete.

Table 29. Percent of rapid chloride ion penetrability for mixes (as $2000 \mathrm{C}=100 \%$ ).

\begin{tabular}{|c|c|c|c|c|c|c|c|c|c|}
\hline Mix I & I-246 & I-247 & I-248 & I-276 & I-277 & I-278 & I-306 & I-307 & I-308 \\
\hline 92 days & 15 & 16 & 26 & 21 & 22 & 27 & 26 & 33 & 41 \\
\hline Mix II & II-246 & II-247 & II-248 & II-276 & II-277 & II-278 & II-306 & II-307 & II-308 \\
\hline 92 days & 13 & 16 & 18 & 15 & 18 & 20 & 21 & 25 & 28 \\
\hline $\begin{array}{c}\text { Mix III } \\
\text { \& IV }\end{array}$ & III-2411 & III-2711 & III-3011 & IV-2411 & IV-2711 & IV-3011 & - & - & - \\
\hline 92 days & 99 & 100 & 102 & 55 & 80 & 92 & - & - & - \\
\hline
\end{tabular}



Figure 1. Probability of sustainable potential of green options for various mixtures according to Taylor Woodrow (resistivity, R) and ASTM C1202 (RCPT, Q).

According to the occurrence of corrosion suggested by Woodrow Tayler [38] and the criteria for chloride ion penetrability with ASTM C1202, green options for anti-corrosion performance of high strength concrete are listed in Table 24-26 and Table28. For all mixtures in the paper, the relationship 
between the resistivity and charge passed were as shown in Figure 1 and Formula 1 . The correlation $\mathrm{r}^{2}$ was equal to 0.933 , which belonged to a highly relevant level.

$$
Q=0.122 R^{2}-34.365 R+2721.344 r^{2}=0.933
$$

Sustainable criteria for anti-corrosion at 92 days were that the resistivity should be greater than 20 $\mathrm{K} \Omega$-cm and the charge passed should be less than $2000 \mathrm{C}$. Mixtures for mix I, mix II, mix IV, and III2411 matched the requirements; however, III-2711 and III-3011 mixtures did not. High strength concrete with a lower water-to-cement ratio (III-2411) could meet the criteria for anti-corrosion, but the cement content was too high to maintain the performance demands. The water content of mix I and mix II (See Table 3-4 and Table 29), w/cm was fixed, the higher the water amount, the lower the charge passed could be displayed the trend. That's water used in mixtures dominated the durability issue. $\mathrm{CO}_{2}$ emissions and resource consumption for the cementitious materials in the mix displayed neither carbon reduction nor sustainability. Multi-pozzolans incorporated in the mixtures (mix I and mix II groups) designed with the DMDA method could enhance the long-term performance and sustainable development during the service life. In order to obtain a carbon dioxide reduction and sustainability for concrete mixture, a proper mix design and an addition of the correct amount of pozzolans will present an optimal option.

\section{Conclusions}

Mixture proportions adopted the densified mixture design algorithm (DMDA) method and water-tocementitious material $(\mathrm{w} / \mathrm{cm})$ ratios from $0.24 \sim 0.30$ with various amounts of pozzolans (mix I \& II). ACI design method acted as control groups (mix III) and added silica fume (mix IV groups). Green options for anti-corrosion of the life cycle inventory of the Leadership in Energy and Environmental Design (LEED) suggested by the Portland Cement Association (PCA) included cement used, $\mathrm{CO}_{2}$ emissions, raw materials, and energy consumption, the compressive strength and surface resistivity development and a rapid chloride ion penetrability test (RCPT), respectively. Test results are summarized as follows:

1. The DMDA applied packing between aggregates by fly ash and slag to enhance the density of aggregate structures for mix I and II. The cement content used was $25 \% \sim 48 \%$ and $20 \% \sim 45 \%$ than that of mix III. Meanwhile, mix IV was $95 \%$.

2. $\mathrm{CO}_{2}$ emissions for mix I and mix II groups, with respect to mix III, were $25 \% \sim 48 \%$ and $20 \%$ $45 \%$. Meanwhile, mix IV was $95 \%$. $\mathrm{CO}_{2}$ emissions were similar to the ratio of cement content used.

3. With respect to mix III, raw materials of cement production for mix I, II, and IV were $25 \% \sim 48 \%$, $20 \% \sim 45 \%$, and $95 \%$, respectively.

4. With respect to mix III, the energy consumption of cement manufacturing for mix I, II, and IV was $26 \% \sim 49 \%, 22 \% \sim 46 \%$, and $95 \%$, respectively.

5. At 28 days, the compressive strength of mix I and mix II were all greater than $100 \%$ with respect to mix III. However, that of mix IV was $91 \% \sim 107 \%$. After 56 days, all the mixtures were above $100 \%$. For II-24 groups (w/cm=0.24 0.30), the compressive strength ratio exceeded $150 \%$ at 92 days. This clearly indicated the effect of incorporating pozzolans.

6. At 28 days, the surface resistivity for mix I, II and IV groups, were all greater than $20 \mathrm{~K} \Omega-\mathrm{cm}$. This was a high potential of anti-corrosion. For mix III after 56 days, only III-2411 was larger than 20 $\mathrm{K} \Omega-\mathrm{cm}$, others had a high corrosion risk in the field of application.

7. RCPT results showed that all mixtures, except III-2711 and III-3011, were below $2000 \mathrm{C}$, had a lower chloride ion penetrability, and higher anti-corrosion levels. Mix I and II indicated that the charge passed were all less than $1000 \mathrm{C}$ to highlight the benefits of pozzolans.

8. This paper attempted to indicate the options of sustainable potential for anti-corrosion of high strength concrete mixtures. Let $\mathrm{Q}_{\mathrm{s}} \leqq 2000 \mathrm{C}$ and $\mathrm{R}_{\mathrm{s}} \geqq 20 \mathrm{~K} \Omega$-cm at 92 days. All the mixtures, except III-2711 and III-3011, could match the above requirements. In order to achieve carbon dioxide reduction and sustainability for a concrete mixture, a proper mix design and addition of the correct amount of pozzolans will present an optimal option. 


\section{References}

1. ACI Committee 363, State-of-the-art report on high-strength concrete (ACI, Farmington Hills, MI, 1997)

2. P. Paultre and D. Mitchell, ACI Concr. Int., 25, 76 (2003)

3. L. Andrew, C. Wonchang, M. Amir, R. Sami, and Z. Paul, ACI Mat. J., 106, 1 (2009)

4. P.K. Mehta, Concrete: microstructure, properties, and materials, fourth edition (McGraw-Hill Education, New York, 2014)

5. A.M. Neville, Properties of concrete, fifth edition (Prentice Hall, San Francisco, USA, 2012)

6. S. Mindess, J.F. Young, and D. Darwin, Concrete, second edition (Pearson, London, 2002)

7. J. Gajda and M. VanGeem, ACI Concr. Int., 24, 59 (2002)

8. ACI Committee 318, Building code requirements for structural concrete (ACI 318-11) and commentary (ACI, Farmington Hills, MI, 2011)

9. American Society for Testing and Materials, C1202-10: Standard test method for electrical indication of concrete's ability to resist chloride ion penetration (ASTM International, West Conshohocken, PA, 2010)

10. D. Laszlo, Concr. Int., 20, 66 (1998)

11. C.L. Hwang, High performance concrete theory and practice (James Publisher, Taipei, 2014)

12. K. Scrivener, Chem. World., March, 62 (2008)

13. K. Scrivener, Ind. Concr. J., 88, 11 (2014)

14. World cement production, 2010-2015, The Statistics Portal (2016) http://www.statista.com/statistics/219343/cement-production-worldwide/

15. A.P. Gurgun, R. Komurlu, and D. Arditi, Procedia Eng., 118, 1145 (2015)

16. C. Meyer, Cem. Concr. Compos., 31, 601 (2009)

17. A. Petek Gursel, E. Masanet, A. Horvath, and A. Stadel, Cem. Concr. Compos., 51, 38 (2014)

18. E. Aprianti, P. Shafigh, S. Bahri, and J. N. Farahani, Constr. Build. Mater., 74, 176(2015)

19. M. Nili and A.M. Salehi, Constr. Build. Mater., 24, 2108 (2010)

20. N. Cobîrzan, A.A. Balog, and E. Moşonyi, Procedia Technol., 19, 506 (2015)

21. M.M. Hossain, M.R. Karim, M. Hasan, M.K. Hossain, and M.F.M. Zain, Constr. Build. Mater., 116, 128 (2016)

22. R.E. Rodríguez-Camacho and R. Uribe-Afif, Cem. Concr. Res., 32, 1851 (2002)

23. K. Celik, C. Meral, M. Mancio, P. Kumar Mehta, and P.J.M. Monteiro, Constr. Build. Mater., 67, 14 (2014)

24. B.B. Sabir, S. Wild, and J. Bai, Cem. Concr. Compos., 23, 441 (2001)

25. H. Dekkiche and A. Taileb, Procedia Eng., 145, 844 (2016)

26. C.L. Champagne and C.B. Aktas, Procedia Eng., 145, 380 (2016)

27. F. Asdrubali, G. Baldinelli, F. Bianchi, and S. Sambuco, Build. Environ., 86, 98 (2015)

28. A.P. Gurgun, R. Komurlu, and D. Arditi, Procedia Eng., 118, 1145 (2015)

29. M.L. Marceau, M.A. Nisbet, and M.G. VanGeem, Life cycle inventory of Portland cement manufacture, PCA R\&D Serial No. 2095 (Portland Cement Association, Skokie, IL, 2005)

30. L. Acquaye, A. Chini, and M. Danso-Amoako, Green options for high temperature cured concrete through the use of fly ash and blast furnace slag (33rd Conference on Our World in Concrete \& Structures, Singapore, August, 25-27, 2008)

31. M.A. Nisbet, M.L. Marceau, and M.G. VanGeem, Environmental life cycle inventory of Portland cement concrete, PCA R\&D Serial No. 2137a (Portland Cement Association, Skokie, IL, 2002)

32. M. Marceau and M.G. VanGeem, Life cycle inventory of slag cement concrete, CTL Project No. 312012 (Construction Technology Laboratories, Skokie, IL, 2003)

33. ECCO EV27, LEED Green Building rating system and concrete (Environment Council of Concrete Organizations, Skokie, IL, 2002)

34. M.L. Marceau, M.A. Nisbet, and M.G. VanGeem, Life cycle inventory of Portland cement concrete, PCA R\&D Serial No. 3007 (Portland Cement Association, Skokie, IL, 2007)

35. American Concrete Institute, Slag cement in concrete and mortar, ACI 233R-03 (ACI, Farmington Hills, MI, 2003) 
36. Y.Y. Chen, B.L.A. Tuan, and C.L. Hwang, Constr. Build. Mater., 47, 340 (2013)

37. ACI Committee 211, Standard practice for selecting proportions for normal, heavyweight, and mass concrete (Reapproved 2009) (ACI, Farmington Hills, MI, 1991)

38. T. Woodrow, Marine durability survey of the Tongue Sands Tower. Concrete in the oceans Technical Report No. 5 (Taylor Woodrow Research Laboratories, Canada, 1980) 